\title{
Effect of epidemiological factors on the severity of stripe rust of wheat caused by Puccinia striiformis
}

\author{
VISHAL GUPTA ${ }^{1 *}$, ARUN KHAJURIA ${ }^{1}$, V.K.RAZDAN ${ }^{1}$, DEEPAK KHER $^{1}$ and ATUL KUMAR ${ }^{2}$ \\ ${ }^{1}$ Faculty of Agriculture, Sher-e-Kashmir University of Agricultural Sciences and Technology of Jammu, Chatha-180009 \\ ${ }^{2}$ Division of Seed Science \& Technology, IARI, New Delhi. \\ Email:vishal94gupta@rediffmail.com
}

\begin{abstract}
The effect of epidemiological factors on the severity of stripe rust in cv. PBW 343 , under early sowing conditions were studied during 2013-14 and 2014-15, rabi seasons. The disease was first appeared in $1^{\text {st }}$ standard meteorological week (SMW) when the crop stage was at 73 days after sowing. Sharp increase in disease severity was observed during $6^{\text {th }}$ to $8^{\text {th }}$ SMW due to the conducive weather conditions which prevailed during the previous fortnight. The meteorological parameters like maximum temperature, minimum temperature, morning vapour pressure, evening vapour pressure and micro meteorological parameters (canopy temperature and soil temperature) had significantly positive correlation with the disease severity in the tested wheat variety, whereas, maximum relative humidity had significant negative correlation. Rainfall had moderately positive correlation with the disease severity. The models generated through stepwise multiple regression analysis revealed that thermic, and hydric variables contributed significantly for the variance in disease severity. Among the three principal components, $\mathrm{Pc}_{1}$ that was contributed by various epidemiological factors (thermic and biological) accounted for maximum variance in disease severity followed by $\mathrm{Pc}_{2}$ (light variables) and $\mathrm{Pc}_{3}$ (hydric variables).
\end{abstract}

Key words: Stripe rust, epidemiology, correlation, stepwise regressions, wheat

By considering the limited resources, production challenges, biotic stresses and aberrations in weather parameters, it is a big challenge to feed the ever increasing population, approximately 125 million tonnes of wheat is estimated to be required by 2030. Stripe rust caused by Puccinia striiformis Westend. is reported as the most destructive one, though earlier it was considered as least damaging but due to changing climatic conditions, has emerged as major disease in last decade (Fu et al., 2009). The disease occurs in areas having cool and moist weather conditions during the wheat growing season (Samborski, H.A.S., 2013). The disease is continually extending the geographical limits, showing movement towards warmer areas due to the appearance of more aggressive pathogen strains, having affiliation towards higher temperatures (Hovmoller et al., 2008; Milus et al., 2009). In India, stripe rust is confined to the cooler regions of the North-West (Punjab, Haryana, U.P. and Jammu and Kashmir) and in Nilgiris hills of South India and is responsible for considerable yield losses (Nagarajan et al., 1984; Kumar et al., 1989). Weather parameters such as temperature, relative humidity and rainfall are the main predisposing factors in stripe rust incidence (Schroder and Hassebrauk, 1964). The plant diseases are a complex interrelationship between weather, amount of inoculum, rate of disease development and host response, therefore a reliable forecasting system is required if management strategies are to be made more effective and economical in reducing yield losses. Keeping this in view, the present study was conducted during rabi seasons of 2013-14 and 2014-15 to study the effect of various metrological factors on the severity of stripe rust of wheat.

\section{MATERIALS AND METHODS}

The experiments were conducted at the University Research Farm, Chatha (32 $43^{\prime} \mathrm{N}, 74^{\circ} 54^{\prime} \mathrm{E}$ ). Based upon the response against disease cv. PBW 343 (highly susceptible) was selected for the study which was sown in $9 \mathrm{~m}^{2}$ plots during last week of October (44 SMW) under early sowing conditions. The experiments were laid out in randomized block design (RBD) with four replications, having row to row spacing of $22.5 \mathrm{~cm}$. The urediniospores spore dust of mixed pathotypes of Puccinia striiformis was collected from Regional Rust Research Centre, Indian Institute of Wheat and Barley Research (ICAR), Flowerdale, Shimla, during Oct., 2013. The inoculums suspension for inoculating test variety was prepared by suspending the 
Table 1: Effect of meteorological parameters on the severity of stripe rust of wheat under early sowing conditions

\begin{tabular}{lcccccccccccccc}
\hline $\mathrm{SMW}$ & $\mathrm{PBW} 343$ & $\begin{array}{c}\mathrm{C}_{\text {Temp. }} \\
\left({ }^{\circ} \mathrm{C}\right)\end{array}$ & $\begin{array}{c}\mathrm{T}_{\text {Max. }} \\
\left({ }^{\circ} \mathrm{C}\right)\end{array}$ & $\begin{array}{c}\mathrm{T}_{\text {Min. }} \\
\left({ }^{\circ} \mathrm{C}\right)\end{array}$ & $\begin{array}{c}\mathrm{RH}_{\text {Max. }} \\
(\%)\end{array}$ & $\begin{array}{c}\mathrm{RH}_{\text {Min }} \\
(\%)\end{array}$ & $\begin{array}{c}\mathrm{M}_{\mathrm{Wv}} \\
\left(\mathrm{km} \mathrm{h}{ }^{-1}\right)\end{array}$ & $\begin{array}{c}\mathrm{Vp}_{\text {Mor }} \\
(\mathrm{mmHg})\end{array}$ & $\begin{array}{c}\mathrm{Vp}_{\text {Evn. }} \\
(\mathrm{mmHg})\end{array}$ & $\begin{array}{c}\mathrm{SS} \\
(\mathrm{hr})\end{array}$ & $\begin{array}{c}\text { Rainfall } \\
(\mathrm{mm})\end{array}$ & $\begin{array}{c}\mathrm{CC}_{\text {Morn. }} \\
(\mathrm{okta})\end{array}$ & $\begin{array}{c}\mathrm{CC}_{\text {Evn }} \\
(\mathrm{okta})\end{array}$ & $\begin{array}{c}\mathrm{S}_{\text {Temp }} \\
\left({ }^{\circ} \mathrm{C}\right)\end{array}$ \\
\hline $\mathbf{1}^{\text {st }}$ & 1.00 & 11.7 & 17.5 & 5.0 & 92.5 & 59.0 & 1.6 & 8.2 & 9.9 & 2.9 & 0.0 & 3.5 & 6.0 & 11.4 \\
$\mathbf{2}^{\text {nd }}$ & 2.83 & 13.0 & 14.7 & 5.8 & 94.0 & 68.5 & 2.0 & 8.3 & 9.3 & 0.8 & 0.6 & 6.5 & 5.0 & 11.8 \\
$\mathbf{3}^{\text {rd }}$ & 6.50 & 14.4 & 15.7 & 4.3 & 95.0 & 71.0 & 4.8 & 7.3 & 10.1 & 7.2 & 0.0 & 0.5 & 0.5 & 11.6 \\
$\mathbf{4}^{\text {th }}$ & 10.83 & 16.0 & 16.0 & 7.9 & 91.5 & 75.0 & 1.6 & 9.3 & 11.0 & 0.0 & 5.0 & 3.0 & 5.0 & 13.3 \\
$\mathbf{5}^{\text {th }}$ & 20.00 & 17.5 & 20.6 & 4.6 & 91.5 & 50.5 & 2.0 & 9.4 & 12.1 & 4.7 & 0.0 & 2.0 & 1.5 & 13.2 \\
$\mathbf{6}^{\text {th }}$ & 26.67 & 18.0 & 19.4 & 10.2 & 82.0 & 64.0 & 3.3 & 11.0 & 12.5 & 3.8 & 0.0 & 6.5 & 3.0 & 13.7 \\
$\mathbf{7}^{\text {th }}$ & 46.67 & 21.0 & 22.6 & 6.1 & 93.0 & 48.5 & 2.1 & 10.7 & 12.8 & 6.2 & 0.0 & 2.5 & 2.5 & 14.9 \\
$\mathbf{8}^{\text {th }}$ & 63.33 & 16.0 & 24.1 & 8.8 & 96.0 & 57.0 & 1.2 & 14.5 & 16.5 & 6.9 & 0.0 & 4.5 & 1.5 & 15.7 \\
$\mathbf{9}^{\text {th }}$ & 68.33 & 17.4 & 17.5 & 11.7 & 88.5 & 77.0 & 1.9 & 13.3 & 14.8 & 0.5 & 0.0 & 5.0 & 5.0 & 14.8 \\
$\mathbf{1 0}^{\text {th }}$ & 71.67 & 18.2 & 21.5 & 9.3 & 89.5 & 54.0 & 3.0 & 12.4 & 12.3 & 5.9 & 14.6 & 2.0 & 2.5 & 15.1 \\
$\mathbf{1 1}^{\text {th }}$ & 75.00 & 17.4 & 22.7 & 9.4 & 81.0 & 52.0 & 2.2 & 11.8 & 13.7 & 4.7 & 9.8 & 4.0 & 4.0 & 16.8 \\
$\mathbf{1 2}^{\text {th }}$ & 81.67 & 21.7 & 27.5 & 11.7 & 87.0 & 46.5 & 2.1 & 15.5 & 15.5 & 6.8 & 0.0 & 2.0 & 0.5 & 19.9 \\
$\mathbf{1 3}^{\text {th }}$ & 85.00 & 22.6 & 24.0 & 14.7 & 83.0 & 72.0 & 5.8 & 14.5 & 14.1 & 2.2 & 3.7 & 5.5 & 5.0 & 20.9 \\
$\mathbf{1 4}^{\text {th }}$ & 86.67 & 25.7 & 27.0 & 12.1 & 82.0 & 47.5 & 5.4 & 8.8 & 15.0 & 9.8 & 18.7 & 1.0 & 0.0 & 20.8 \\
\hline
\end{tabular}

$\mathrm{C}_{\text {Temp }}=$ Canopy temperature, $\mathrm{T}_{\text {Max }}=$ Maximum temperature, $\mathrm{T}_{\text {Min. }}=$ Minimum temperature, $\mathrm{RH}_{\text {Max.. }}=$ Maximum relative humidity, $\mathrm{RH}_{\mathrm{Min} .}=$ Minimum relative humidity, $\mathrm{M}_{\mathrm{Wv} .}=$ Mean wind velocity, $\mathrm{Vp}_{\mathrm{Mor}}=$ Morning vapour pressure, $\mathrm{Vp}_{\mathrm{Evn.} .}=$ Evening vapour pressure, $\mathrm{SS}=$ Sunshine, $\mathrm{CC}_{\text {Morn. }}=$ Morning cloud cover, $\mathrm{CC}_{\text {Evn. }}=$ Evening cloud cover, $\mathrm{S}_{\text {Temp. }}=$ Soil temperature

inoculum dust in sterile distilled water $(95 \mathrm{ml})$ to which $5 \mathrm{ml}$ of Tween-20 was added (Broers and Lopez-Atilano, 1994). The field was irrigated frequently to maintain adequate moisture conditions for the buildup of disease. The effect of different epidemiological factors viz., minimum temperature, maximum temperature $\left({ }^{\circ} \mathrm{C}\right)$, maximum relative humidity, minimum relative humidity $(\%)$, rainfall ( $\mathrm{mm}$ ), soil temperature $\left({ }^{\circ} \mathrm{C}\right)$, canopy temperature $\left({ }^{\circ} \mathrm{C}\right)$, cloud cover (Okta), wind speed $(\mathrm{km} / \mathrm{h})$, sunshine hours (hrs/day), and vapour pressure $(\mathrm{mmHg})$ were studied on the development of stripe rust on the PBW 343. The metrological data were collected from Agro-meteorological section of the University. The canopy temperature was recorded with infrared thermometer (Ramson make) and soil temperature with soil thermometer (Japson make). From the last week of December onwards the plants were monitored regularly to observe the initial foci of Puccinia striiformis. Disease severity (per cent infection) was recorded using modified Cobb's scale (Peterson et al., 1948) on randomly tagged plants (4/plot). The severity of stripe rust was recorded starting from the $\mathrm{I}^{\text {st }}$ to $14^{\text {th }} \mathrm{SMW}$. Correlation and stepwise regression analysis were conducted using SPSS 16 (Jamshed et al. 2008). The epidemiological and disease severity data of the selected wheat variety were further subjected to Principal Component Analysis (Xi et al. 2013).

\section{RESULTS AND DISCUSSION}

\section{Effect of meteorological parameters}

During both the seasons (2013-14 and 2014-15) under early sowing dates, primary infection appeared in $\mathrm{I}^{\text {st }}$ SMW ( $2^{\text {th }}$ Jan. 2013 and $4^{\text {th }}$ Jan. 2014, respectively) in cv. PBW 343 having severity of 1.0 per cent when the crop was at jointing growth stage ( 73 days after sowing) and the corresponding weather parameters (before one-week) having maximum temperature of $17.5^{\circ} \mathrm{C}$, minimum temperature of $5^{\circ} \mathrm{C}$, maximum relative humidity $(\mathrm{RH})$ of 92.50 and minimum of 59 per cent, mean wind velocity of $1.6 \mathrm{~km} \mathrm{~h}^{-1}$, vapour pressure (morning $8.2 \mathrm{mmHg}$ and evening $9.9 \mathrm{mmHg}$ ), sunshine $\left(2.9 \mathrm{~h} \mathrm{day}^{-1}\right)$, cloud cover (morning 3.5 and evening $6.0 \mathrm{okta})$, soil temperature $\left(11.4^{\circ} \mathrm{C}\right)$ and canopy temperature $\left(11.7^{\circ} \mathrm{C}\right)$ (Table 1$)$.

The disease gradually progressed with the age of crop and increased sharply from 26.6 to 63.3 per cent in PBW 343, during $6^{\text {th }}$ to $8^{\text {th }}$ SMW when the crop was at heading to milk stage (108 to $122 \mathrm{DAS}$ ), with maximum temperature of 19.4 to $24.1^{\circ} \mathrm{C}$, minimum temperature of 10.2 
Table 2: Correlation of meteorological parameters with the severity of stripe rust of wheat

\begin{tabular}{lc}
\hline Meteorological parameters & PBW 343 \\
\hline $\mathrm{T}_{\text {Max. }}$ & 0.830 \\
$\mathrm{~T}_{\text {Min. }}$ & 0.828 \\
$\mathrm{RH}_{\text {Max. }}$ & -0.586 \\
$\mathrm{RH}_{\text {Min. }}$ & -0.361 \\
$\mathrm{M}_{\text {Wvv. }}$ & 0.312 \\
$\mathrm{Vp}_{\text {Morn. }}$ & 0.754 \\
$\mathrm{Vp}_{\text {Evn. }}$ & 0.867 \\
$\mathrm{SS}$ & 0.396 \\
$\mathrm{Rainfall}$ & 0.502 \\
$\mathrm{C}_{\text {Temp. }}$ & 0.779 \\
$\mathrm{CC}_{\text {Morn. }}$ & -0.075 \\
$\mathrm{CC}_{\text {Evn. }}$ & -0.290 \\
$\mathrm{~S}_{\text {Temp. }}$ & 0.899 \\
\hline
\end{tabular}

Values in bold are highly significant at $(\mathrm{p}=0.05)$

to $8.8^{\circ} \mathrm{C}$, maximum $\mathrm{RH}$ of 82 to 96 per cent, minimum RH of 64 to 57 per cent, mean wind velocity of 3.3 to $1.2 \mathrm{~km} \mathrm{~h}^{-1}$, vapour pressure (morning 11 to $14.5 \mathrm{mmHg}$ and evening 12.5 to $16.5 \mathrm{mmHg}$ ), sunshine ( 3.8 to $6.9 \mathrm{~h} \mathrm{day}^{-1}$ ), cloud cover (morning 6.5 to 4.5 and evening 3.0 to $1.5 \mathrm{okta}$ ), soil temperature $\left(13.7\right.$ to $\left.15.7^{\circ} \mathrm{C}\right)$ and canopy temperature (18 to $\left.16^{\circ} \mathrm{C}\right)$.

At the maturity stage (164 DAS) in $14^{\text {th }}$ SMW, maximum disease severity of 86.6 per cent was recorded in PBW 343 with maximum temperature of $27^{\circ} \mathrm{C}$ and minimum of $12.1^{\circ} \mathrm{C}$, maximum RH of 82 and minimum of 47 per cent, mean wind velocity of $5.4 \mathrm{~km} \mathrm{~h}^{-1}$, morning vapour pressure of 8.8 and evening of $15 \mathrm{mmHg}$, sunshine of $9.8 \mathrm{~h} \mathrm{day}^{-1}$, rainfall of 18.7 $\mathrm{mm}$, morning cloud cover of $1.0 \mathrm{okta}$, soil temperature of $20.8^{\circ} \mathrm{C}$ and canopy temperature of $25.7^{\circ} \mathrm{C}$.

Prevalence of conducive environmental conditions viz., low temperature $\left(11.2^{\circ} \mathrm{C}\right)$, high maximum $\mathrm{RH}(92 \%)$, with continuous cloud cover (5.0 okta) along with phenological vulnerable stages of host (jointing, stem elongation and tillering) were found favourable for the initiation of primary infection of stripe rust, which was found to be in confirmation with the findings of Stubbs (1967) and Chen et al. (2014) who reported that stripe rust frequently occurred in the areas having cool and moist conditions with low temperature of 7 to $12^{\circ} \mathrm{C}$. Activities of P. striformiis such as germination, penetration and development were hindered due to rise in temperature during April which prevented further disease development as a result of heat and dryness (Salman et al., 2006; Lal et al., 2008).

\section{Correlation between disease severity and meteorological parameters}

Under early sowing dates, in PBW 343, temperature (maximum and minimum), vapour pressure (morning and evening), canopy temperature and soil temperature had a significantly positive correlation with the disease severity having correlation co-efficient $(\mathrm{R})$ values of $0.83,0.83$, $0.75,0.87,0.78$ and 0.90 , respectively, followed by rainfall $(\mathrm{R}=0.50)$ which was positively but moderately correlated. Whereas, maximum $\mathrm{RH}(\mathrm{R}=-0.59)$ had a significant but negative correlation with the disease severity (Table 2). Ahmed et al. (2010) observed that stripe rust severity had strong correlation with maximum temperature, minimum temperature and sunshine hours having ' $R$ ' value of 0.45 , 0.3 and 0.47, respectively. Christensen et al. (1993) also recorded that temperature in January and February was significantly correlated with severity of stripe rust of wheat.

\section{Stepwise regressions}

In PBW 343, under the early sowing dates, the regression equation developed was highly significant in predicting the severity of stripe rust (Table 3). Among different explanatory variables, 92.6 per cent variation was explained by the cumulative effect of evening vapour pressure, morning vapour pressure and rainfall. Thereby predicting that an increase/decrease in disease severity by 6.32 per cent per week by per unit increase/decrease in evening vapour pressure, if all the other predictors remained constant ( $95 \%$ CI from 1.13 to $11.50 \%$ ). Whereas, 5.61 per cent increase/decrease in disease severity was predicted per week by per unit increase/decrease in morning vapour pressure if all the other predictors remained constant $(95 \%$ CI from 1.28 to $3.54 \%$ ). The developed regression model was validated with independent data set in cv. Agra local which showed that showed that 97.4 per cent variation was explained by commutative effects of evening vapour pressure, rainfall, morning vapour pressure and canopy temperature. Observed versus prediction of disease severity values showed good association in PBW 343 and Agra Local $\left(\mathrm{R}^{2}=0.92\right.$ and 0.93$)$. The lower tolerance $(<1)$ and $\operatorname{VIF}(<10)$ showed the least multi-collinearity (inter correlated effect). Thermal and harydic variables were responsible for 94 to 99 per cent and 91 to 98 per cent variation in causing leaf rust severity in wheat, respectively (Jamshed et al., 2008). Since, environment is a complex system, it is influenced by many 
Table 3: Stepwise regression of meteorological parameters with the severity of stripe rust of wheat

\begin{tabular}{llccccr}
\hline Variety & Stepwise Regression Equation & $\mathrm{R}^{2}$ & $\begin{array}{c}\mathrm{F} \\
\text { value }\end{array}$ & $\begin{array}{c}95 \% \mathrm{C} \text { I } \\
\text { Lower-upper }\end{array}$ & Tolerance & VIF \\
\hline PBW 343 & $\mathrm{Y}=-106.12+6.32 \mathrm{X}_{6}+5.61 \mathrm{X}_{3}$ & 0.926 & 41.9 & $\mathrm{X}_{6}=1.13-11.50$ & .306 & 3.264 \\
& $+2.41 \mathrm{X}_{5}$ & & & $\mathrm{X}_{3}=1.28-3.54$ & .832 & 1.202 \\
& & & & $\mathrm{X}_{5}=1.34-9.88$ & .317 & 3.154 \\
Agra Local & $\mathrm{Y}=-102.44+3.13 \mathrm{X}_{6}+1.90$ & 0.974 & 41.8 & $\mathrm{X}_{6}=-1.86-8.14$ & .233 & 4.300 \\
& $\mathrm{X}_{5}+5.06 \mathrm{X}_{3}+2.57 \mathrm{X}_{4}$ & & & $\mathrm{X}_{5}=.84-2.96$ & .669 & 1.494 \\
& & & & $\mathrm{X}_{3}=1.46-8.66$ & .315 & 3.172 \\
& & & & $\mathrm{X}_{4}=.41-4.72$ & .425 & 2.351 \\
\hline
\end{tabular}

$\mathrm{Y}=$ Disease severity, $\mathrm{Vp}_{\mathrm{Morn}}=\left(\mathrm{X}_{3}\right), \mathrm{C}_{\mathrm{Tmp}}=\left(\mathrm{X}_{4}\right)$, Rainfall $=\left(\mathrm{X}_{5}\right), \mathrm{V} \mathrm{p}_{\mathrm{Even}}=\left(\mathrm{X}_{6}\right)$

Table 4:Principal component analysis of meteorological parameters of stripe rust of wheat

\begin{tabular}{lcccc}
\hline $\begin{array}{l}\text { Meteorological } \\
\text { parameters }\end{array}$ & Community & $\mathrm{Pc}_{1}$ & $\mathrm{Pc}_{2}$ & $\mathrm{Pc}_{3}$ \\
\hline Agra Local & .964 & .908 & .192 & .322 \\
$\mathrm{PBW} 343$ & .952 & .926 & .169 & .256 \\
$\mathrm{~T}_{\text {Max. }}$ & .934 & .801 & .528 & .117 \\
$\mathrm{~T}_{\text {Min. }}$ & .946 & .864 & -.246 & .374 \\
$\mathrm{RH}_{\text {Max. }}$ & .701 & -.554 & .146 & -.611 \\
$\mathrm{RH}_{\text {Min. }}$ & .701 & -.278 & -.785 & .079 \\
$\mathrm{M}_{\text {Wvv. }}$ & .721 & .117 & .110 & .834 \\
$\mathrm{Vp}_{\text {Morn. }}$ & .911 & .902 & -.119 & -.289 \\
$\mathrm{Vp}_{\text {Evn. }}$ & .889 & .911 & .225 & -.092 \\
$\mathrm{SS}$ & .912 & .202 & .917 & .174 \\
$\mathrm{Rainfall}$ & .661 & .221 & .250 & .742 \\
$\mathrm{C}_{\text {Temp. }}$ & .825 & .693 & .349 & .473 \\
$\mathrm{CC}_{\text {M orn. }}$ & .730 & .173 & -.807 & -.221 \\
$\mathrm{CC}_{\text {E vn. }}$ & .807 & -.151 & -.882 & -.080 \\
$\mathrm{~S}_{\text {Temp. }}$ & .927 & .859 & .198 & .386 \\
Variance (\%) & - & 59.49 & 16.55 & 9.28 \\
Cumulative (\%) & - & - & 76.04 & 85.32 \\
\hline & & & &
\end{tabular}

variables, where change in one leads to the change in another. Precipitation (rainfall) washes inoculum from the air, reduces light intensity, lowers temperatures and increases the probability of dew formation for several succeeding days, which favours disease development and spread (Eversmeyer and Burleigh, 1969).

\section{Principal component analysis}

Three principal components $\left(\mathrm{Pc}_{1}, \mathrm{Pc}_{2}\right.$ and $\left.\mathrm{Pc}_{3}\right)$ were generated, in which Agra Local and PBW 343, maximum temperature, minimum temperature, morning vapour pressure, evening vapour pressure, canopy temperature and soil temperature contributed maximum in principal component one $\left(\mathrm{Pc}_{1}\right)$ having coefficient values of 0.90 , $0.92,0.80,0.87,0.90,0.91,0.69$ and 0.85 , followed by minimum relative humidity, sunshine hours, morning cloud cover and evening cloud cover in $\mathrm{Pc}_{2}$ having coefficient of $-0.78,0.92,-0.81$ and -0.88 , while, maximum relative humidity, mean wind velocity and rainfall contributed in $\mathrm{Pc}_{3}$ having coefficient of $-0.61,0.83$ and 0.74 , respectively. Among the 85.32 per cent cumulative variance explained by epidemiological factors, $\mathrm{Pc}_{1}$ accounted for 59.49 per cent, followed by 16.55 and 9.28 per cent variance by $\mathrm{Pc}_{2}$ and $\mathrm{Pc}_{3}$, respectively which was in confirmation with the findings of others workers who reported that temperature, moisture and light have major role in uredinial infection process and spread of the disease (Chen et al., 2014).

\section{REFERENCES}

Ahmed, S., Afzal, L.R.N., Iqbal, Z., Akhtar, N., Iftkar, Y. and Kamran, M. (2010). Prediction of yield losses in wheat (Triticum aestivum) caused by yellow rust in relation to epidemiological factors in Faisalabad. Pak. J. Bot., 42(1): 401-407.

Broers, L.H.M. and Lopez-Atilano, R.M. (1994). Amethod of inoculating adult wheat plants with urediospores of Puccinia striiformis to measure components of resistance. Pl. Dis., 78: 353-357

Chen, W., Wellings, C., Chen, X.M., Kang, Z.S. and Liu, T.G. (2014). Wheat stripe (yellow) rust caused by Puccinia striiformis f. sp. tritici. Mol. Pl. Path., 15(5):433-446.

Chirstensen, K., Jorgensen, L.N. and Secher, B.J.M. (1993). Development of a yellow rust model based on historical data. Proceeding of the $10^{\text {th }}$ Danish Plant Protection 
Conference. Plantevaernscentret, pp 71-78.

Eversmeyer, M.G. and Burleigh, J.R. (1969). A method of predicting epidemic development of wheat leaf rust. Phytopath., 60: 805-811.

Fu, D. L., Uauy, A., Distelfeld, A., Blechl, L., Epstein, X., Chen, H., Sela, T. F. and Dubcovsky, J. (2009). A kinase-start gene confers temperature-dependent resistance to wheat stripe rust. Sci., 323(591): 1357-1360.

Hovmoeller, M. S, Yahyaoui, A. H., Milus, E. A. and Justesen, A. F. (2008). Rapid global spread of two aggressive strains of a wheat rust fungus. Mol. Eco., 17: 3818-3826.

Jamshed, U., Nasim, G. and Rasool, G. (2008). Correlation and regression for prediction of wheat leaf rust in Bahawalpur and Multan using relevant meteorological data. Mycopath., 6(1\&2): 23-29.

Kumar, J., Nayar, S.K., Prashar, M., Bhardwaj, S.C. and Singh, S.B. (1989). A new pathotype of Puccinia striformis tritici in India. Pl. Dis. Res., 52(1): 221-222.

Lal, H.C., Upadhya, J.P., Jha, A.K. and Kumar, A. (2008). Comparison of weather based models to predict rust of lentil on cultivar Sehore 74-3. J. Myco. Pl. Path., 38: 287-290.

Milus, E.A., Kristensen, K. and Hovmoller, M. (2009). Evidence for increased aggressiveness in a recent widespread strain of Puccinia striiformis f.sp. tritici causing stripe rust of wheat. Phytopath, 99: 89-94.

Nagrajan, S., Bahaur, P. and Nayar, S. K. (1984). Rust Bulletin, 27: 28-31.

Peterson, R.F., Campbell, A.B. and Hannah, A.E. (1948). A diagram scale for estimating rust severity on leaves and stems of cereals. Can. J. Res. Sec., 26: 496-500.

Salman. A., Khan, M. A. and Hussain, M. (2006), Prediction of yield losses in wheat varieties/lines due to leaf rust in Faislabad. Pak. J. Phytopath., 18(2): 178-182.

Samborski,H.A.S. (2013). Impact of weather on occurrence of brown rust of wheat in southeast of Lubin, Poland. $J$. Agrometeorol. 15(2): 103-108.

Schroder, J. and Hassebrauk, K. (1964). Undersuchungen uber die Keimung der Uredosporen des Gelbrostes (Puccinia striiformis West). Zentrab. Bakteriol. Parasitenk. Infektionskrank. Hyg., 118: 622-657.

Stubbs, R. W.(1967). Influence of light intensity on the reactions of wheat and barley seedlings to Puccinia striiformis. Phytopath., 57: 615-619.

Xi, K., Chen, X. M., Capettini, F., Falconi, E., Yang, R. C., Helm, J. H., Holtz, M. D., Juskiw, P., Kumar, K., Nyachiro, J. and Turkington, T. K. (2013). Multivariate analysis of stripe rust assessment and reactions of barleyin multi-location nurseries. Can .J. Pl. Sci., 93: 209-219. 